\title{
Thickness variation of the sedimentary cover in the South Western Desert of Egypt as deduced from Bouguer gravity and drill-hole data using neural network method
}

\author{
Mohamed Abdel Zaher ${ }^{1}$, M. M. Senosy², M. M. Youssef ${ }^{2}$, and Sachi Ehara ${ }^{1}$ \\ ${ }^{1}$ Faculty of Engineering, Kyushu Univ., 744 Motooka, Nishi-ku, Fukuoka 819-0395, Japan \\ ${ }^{2}$ Geology Department, Faculty of Science, Assiut University, Assiut, Egypt
}

(Received July 4, 2008; Revised December 5, 2008; Accepted December 9, 2008; Online published July 27, 2009)

\begin{abstract}
The Bouguer anomaly map of scale 1:500,000 and the lithological logs of more than 120 deep wells distributed in the Southern part of Western Desert of Egypt were used to determine the thickness of the sedimentary cover containing the main sandstone water formation. The predominant structures affecting both the basement rock and the sedimentary cover were also studied. Gravity stripping approach was applied to separate density anomalies within the sedimentary fill from the influence of deeper levels in the crystalline crust. The study indicated that the surface of the basement rock is highly rugged and mostly controlled by structures causing variation of the sedimentary cover thickness from location to other all over the area. Isopach maps were constructed based on the Artificial Neural Network (ANN) model which is considered a best method for that operation. The maximum thickness of sandstone formations is recorded at west Oweinat, southwest of Aswan, Dakhla oasis and west of Qena town. As this formation is the main water aquifer in the study area, therefore these locations are characterized by the presence of huge amount of ground water. Accordingly, these areas must be taking the priority in the programs of sustainable development in southern Egypt.
\end{abstract}

Key words: Bouguer anomaly map, isopach map, Dahkla, Kharga, Oweinat, Aswan, Bir Safsaf.

\section{Introduction}

The present study covers the southern part of the Western Desert of Egypt about $160,000 \mathrm{~km}^{2}$ bounded by latitudes $22^{\circ} 00^{\prime}-26^{\circ} 30^{\prime} \mathrm{N}$, and longitudes $28^{\circ} 30^{\prime}-33^{\circ} 00^{\prime} \mathrm{E}$ (Fig. 1). It is an arid region with no marked drainage lines except from some gullies draining toward the Nile valley. The aim of the present study is to evaluate the subsurface structures and tectonic framework of the area and to determine the whole thickness of the sedimentary cover, consequently the basement tectonic features, which probably control the thin cover. Data obtained from drilled holes together with gravity survey and some geological information in the study area is used for drawing the configuration of the underlying basement complex.

Models of the depth of sedimentary cover in that area were made by construction of Artificial Neural Network (ANN). ANN estimate the thickness of sedimentary rocks based on the back propagation algorithm, which is a gradient descent system that tries to minimize the mean square error (MSE). Also, cross sections were constructed in order to show both the vertical and the horizontal relationships among various rock bodies.

\section{Geological Setting}

The Western Desert is a huge platform with mean elevation of $500 \mathrm{~m}$ a.s.l. consisting of thick-layered sedimen-

Copyright (c) The Society of Geomagnetism and Earth, Planetary and Space Sciences (SGEPSS); The Seismological Society of Japan; The Volcanological Society of Japan; The Geodetic Society of Japan; The Japanese Society for Planetary Sciences; TERRAPUB tary rocks largely unaffected by tectonic disturbances (Said, 1962). Sandstone with a slight northward regional slope and dip makes up the largest part of the exposed and subsurface strata. Carbonate strata are confined to the resistant limestone cap of the Egyptian plateau. The geologic units are adopted from the geologic map of the Egypt at a scale of 1:500,000 (E. G. P. C. and Conoco Coral, 1987) (Fig. 2).

Generally, the study area is characterized by two large intracratonic basins; Dakhla basin and Nile Valley basin, separated from each other by Kharga uplift which trends in $\mathrm{N}-\mathrm{S}$ direction. These basins are delimited by the OweinatBir Safsaf-Aswan uplift at the south, which trends in E-W direction at the southern rim of the Dakhla basin and NESW direction at the southern margin of the upper Nile basin and separates the deep intracratonic basins from the more shallow basins of North Sudan (El-Etr et al., 1982).

\section{Materials and Methods}

Generally, geophysical methods respond to the physical properties of the sub-surface media (rocks, sediments, water, subsurface geological structures, etc.), and the gravity method considers a useful and powerful geophysical tool that can produce useful information about the subsurface density. The present study depends on the Bouguer anomaly map at a scale 1:500,000 compiled by the Egyptian General Petroleum Corporation (E. G. P. C.) (1980) (Fig. 3). The main rock types in the study area are granitic basement rock, sandstone, siltstone, shale, and limestone. Senosy (2003) has determined the density of the dominant lithologic units in El-Kharga Oasis (Table 1) by comparison be- 


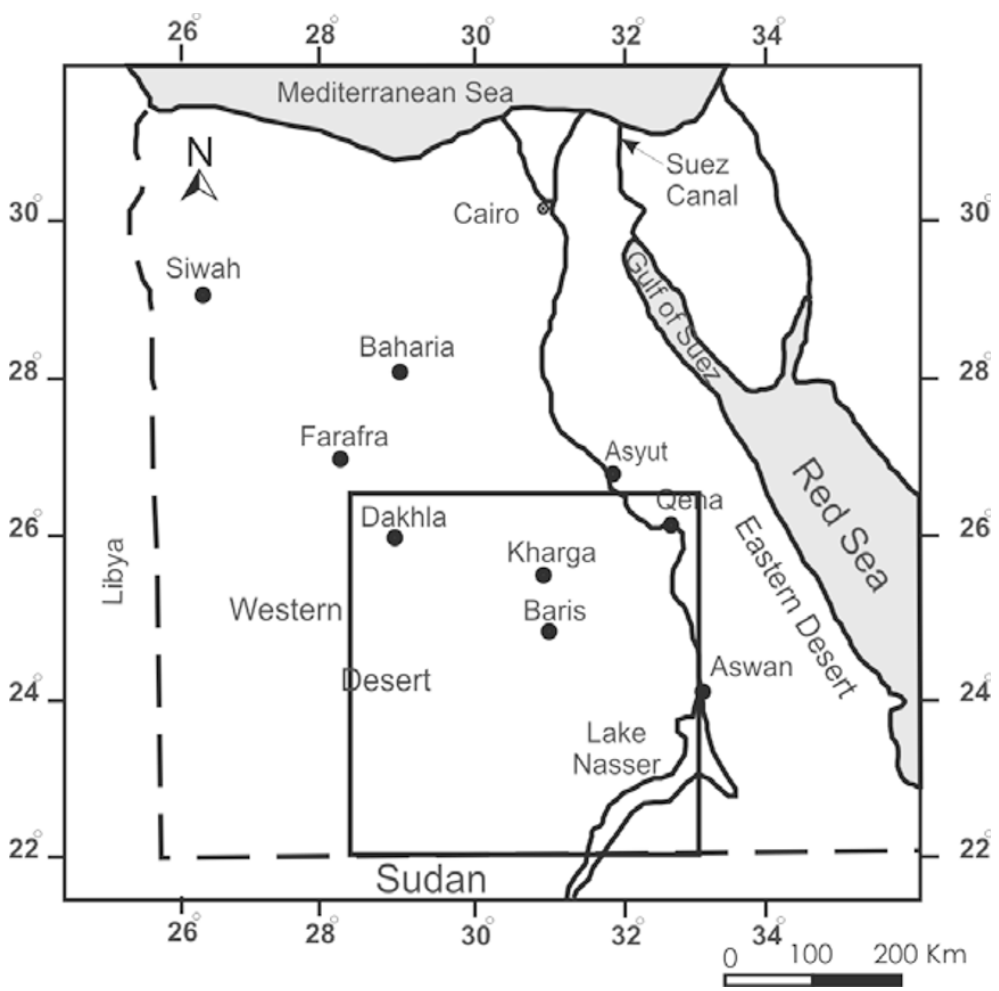

Fig. 1. Location map of the study area bounded by latitudes $22^{\circ} 00^{\prime}-26^{\circ} 30^{\prime} \mathrm{N}$, and longitudes $28^{\circ} 30^{\prime}-33^{\circ} 00^{\prime} \mathrm{E}$.

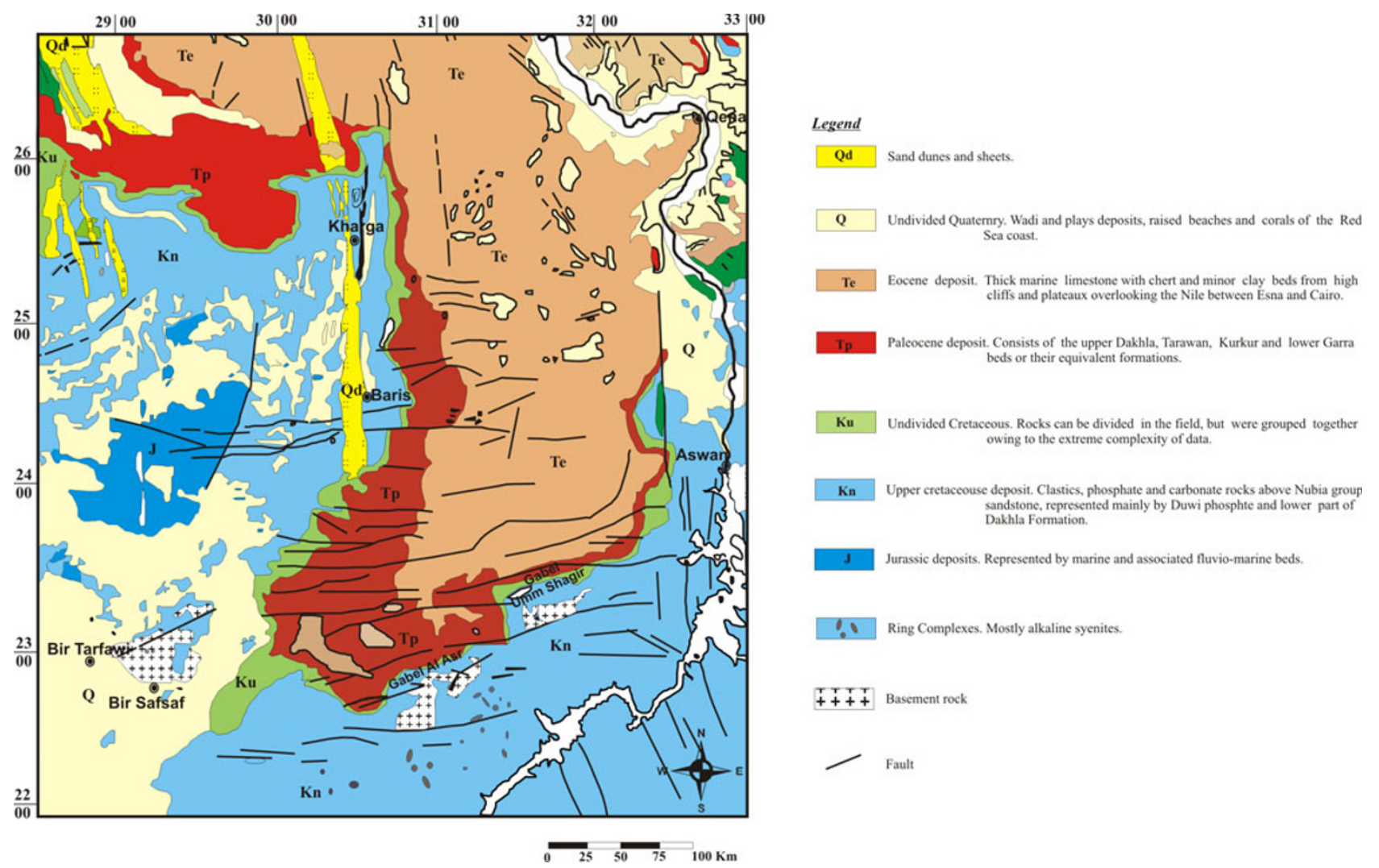

Fig. 2. Geologic map of the study area at a scale of 1:500,000 (E. G. P. C. and Conoco Coral, 1987). 


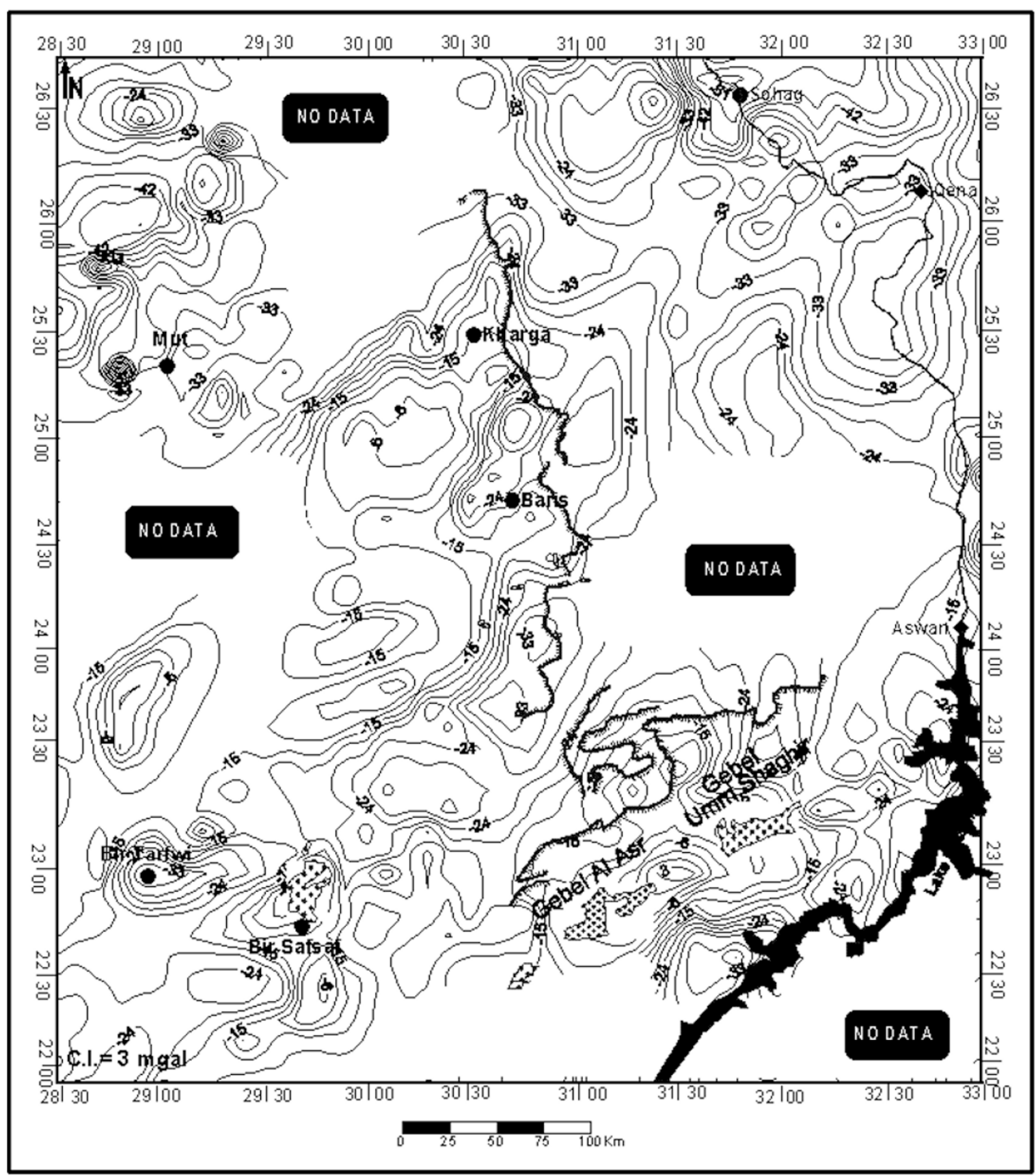

Fig. 3. Bouguer anomaly map of the study area with contour interval 3 mgal surveyed by Egyptian General Petroleum Company (1980).

tween density contrast ranges of different rocks reported in literature (e.g., Nettleton, 1976; Telford et al., 1990; Parasniss, 1997; and others) and density measurements derived from Formation Density Compensated logs (FDC) of some deep wells in northwestern desert of Egypt by Abu El-Ata and Abd El-Nabi (1985).

The lithological units in the southern part of the Western Desert are probably similar in composition; so the density contrasts determined by Senosy (2003) can be widely used in all parts of the study area. Accordingly, the density of the variegated shale formation ranges between 2.63 and $2.65 \mathrm{~g} / \mathrm{cm}^{3}$ and that of the Nubian sandstone between 2.65 and $2.67 \mathrm{~g} / \mathrm{cm}^{3}$. By taking the base density of the outer crust as $2.67 \mathrm{~g} / \mathrm{cm}^{3}$, the apparent density contrast of the shale formation range between -0.02 and $-0.04 \mathrm{~g} / \mathrm{cm}^{3}$ and
Table 1. Average density and density contrast of the main rock types in El-Kharga Oasis (Senosy, 2003).

\begin{tabular}{|c|c|c|}
\hline Rock type & Density $\mathrm{g} / \mathrm{cm}^{3}$ & Density contrast $\mathrm{g} / \mathrm{cm}^{3}$ \\
\hline Nubian sandstone & 2.65 to 2.67 & to -0.02 \\
\hline Variegated shale & 2.63 to 2.65 & -0.02 to -0.04 \\
\hline Limestone & 2.5 to 2.7 & -0.17 to 0.03 \\
\hline Granite & 2.67 & |||||||||| \\
\hline
\end{tabular}

between 0 to $-0.02 \mathrm{~g} / \mathrm{cm}^{3}$ in case of Nubian sandstone, which overlying country rocks of the basement.

More than 120 wells drilled in the southern part of the western Desert have been used for this study (Fig. 4). These wells data, scattered in the whole area, were collected from 


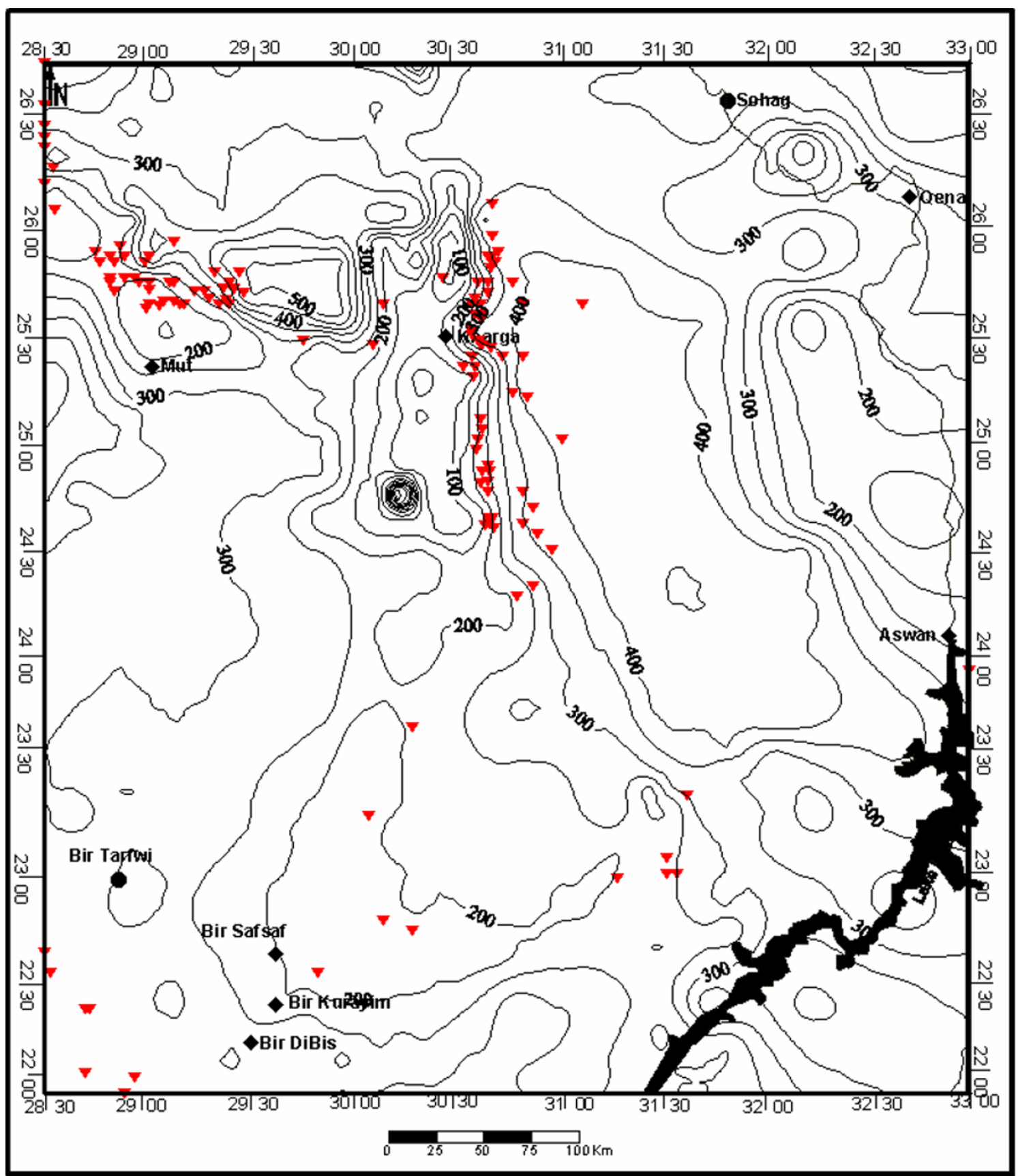

Fig. 4. Locations of the used well logs plotted on the topographic map of the study area digitized from the topographic sheets scale $1: 100,000$ modified by Egyptian Survey Authority.

different sources including Groundwater Center in Kharga, Branch of National Academy of Science in Kharga, Geology Department of Martin-Luther University in Germany and other variable published literatures (such as Barakat and Milad, 1966; Hendriks et al., 1984; Wycisk, 1987; Heinl and Thorweihe, 1993 and others). Available subsurface data have been obtained from deeper water wells recently drilled at east of Oweinat by REGWA-Egypt company. Such data made a first attempt at lithostratigraphic correlation of the subsurface condition of the area.

\section{Gravity Data Processing}

The major problem in gravity interpretation is separating anomalies of interest from the overlapping effects of other features; usually the main obscuring affects result from deeper features. The Bouguer anomaly map of any area is the cumulative gravity effects of the various lithostratigraphic units composing the sedimentary cover as well as that of the basement complex, which we can assume that the total gravity effect of anomalous bodies is acquired by summation of the gravity effects of $n$-sided vertical prisms with horizontal bases.

At the study area, a technique has been applied, such technique called gravity stripping. The stripping procedure has a more accurate physical foundation than any other mathematical method of gravity field analysis, provided that the geometry and density of the disturbing bodies are known with sufficient accuracy. This technique involves several 


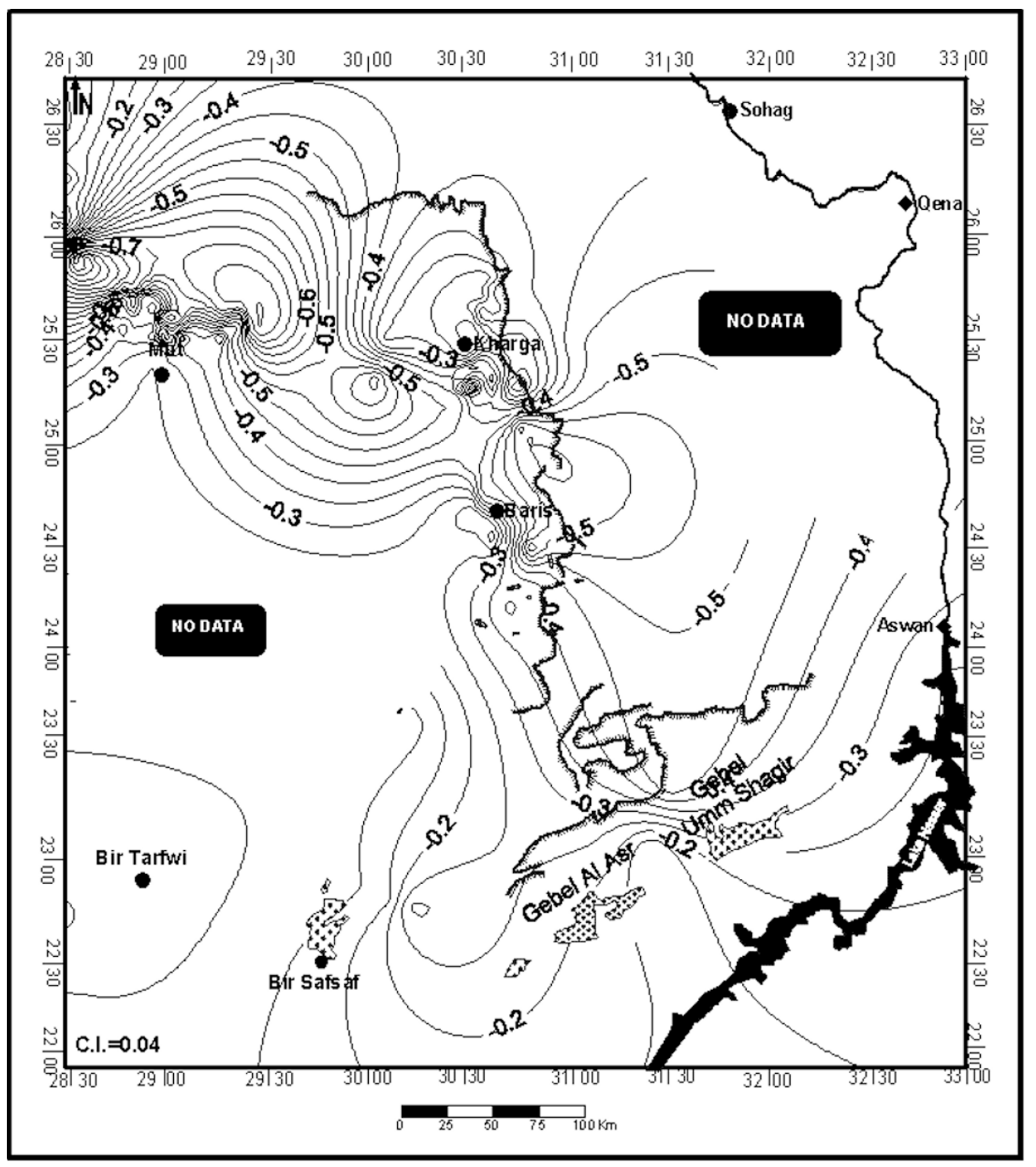

Fig. 5. Gravity effect of the sedimentary rocks with contour interval 0.04 mgal.

steps including: Preparation of the using available data (e.g. observed Bouguer anomaly map, geometry of upper and lower surface of the rock units which are obtained from lithologic well logging, and density distribution), and then calculate the gravity effects of each of the layers incorporating the upper and lower geometrical boundaries and density distributions and summing of the effects of individual layers to obtain a summed gravity effect for the sedimentary succession, and finally subtracted this effect from the original Bouguer anomaly map, to obtain a gravity anomaly only caused by the structures below the sedimentary rocks. However, the workable equation is:

$$
\Delta g=2 \pi G \rho h
$$

Where; $\Delta g$ is the gravity effect of a certain unit in gal,
$G$ is the international gravitational constant, which equals $6.67 \times 10^{-8}$ c.g.s. unit, $\rho$ is the density contrast between the unit density and the basement density $\left(2.67 \mathrm{~g} / \mathrm{cm}^{3}\right)$ and $h$ is the unit thickness in $\mathrm{cm}^{3}$. The gravity effect of the whole sedimentary cover has been calculated (Fig. 5) and then subtracted from the Bouguer anomaly map, the result is the Bouguer anomaly map on the top of the basement with no effect from the overlain sediments (Fig. 6).

Qualitative interpretation of the gravity data provides available information, for examples the extension of faults and intrusions can be qualitatively determined from a close examination of data. On the Bouguer anomaly map of the study area (Fig. 3) The positive anomaly is mainly due to uplift of more denser basement rock in Gabel Umm shaghir and Gabel El Asr, however, the lower gravity values in- 


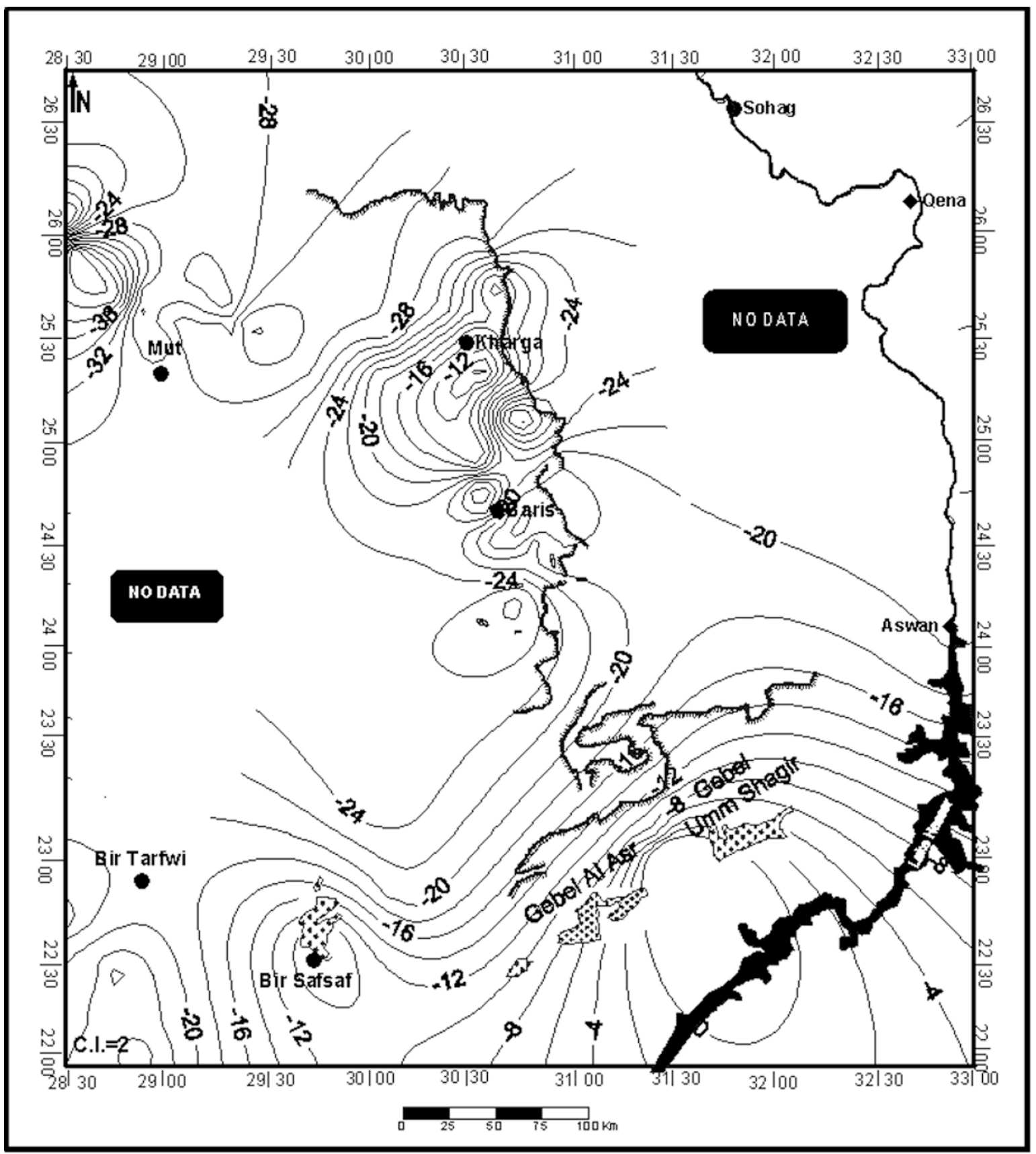

Fig. 6. Gravity map on the top of the basement rock with contour interval 2 mgal.

dicate sedimentary basins. In the gravity map on the top of basement rock (Fig. 6), the major gravity anomalies on the Bouguer anomaly map are separated into isolated close anomalies pointing to the undulation of the basement surface. Where the distribution of positive gravity anomalies in this map mainly due to structures and lithologic variation within the basement rocks. The negative anomalies denoting to acidic rocks, while the positive ones indicating mafic or alkalic rocks.

Generally, Comparison of the Bouguer anomaly map and the stripped gravity map can conclude that the difference between the gravity values from the Bouguer anomaly map, which represents the summation of the gravitational attractions of all subsurface sources including basement rock as well as sedimentary rocks, and the gravity anomaly values on the top of the basement rock are less than 5 mgal. So, we can say that main influence on the Bouguer anomaly map is basement rocks and all sedimentary cover have less effect on Bouguer anomaly map; it can appear very clearly on the gravity map of sedimentary rock (Fig. 5).

The analysis of the gravity lineaments in the study area involves the lineament on the Bouguer anomaly map and gravity map on the top of the basement (Figs. 7 and 8). Gravity lineaments can define as a disruption in the contour pattern. Obviously the disruptions are caused by the juxtaposition of blocks of rocks of varying composition (varying density contrast) at various places along opposite sides of the lineament. This line of reasoning leads to the lineament must be a fault. Some faults, which probably belong to one and the same system, possess opposite sense of dis- 


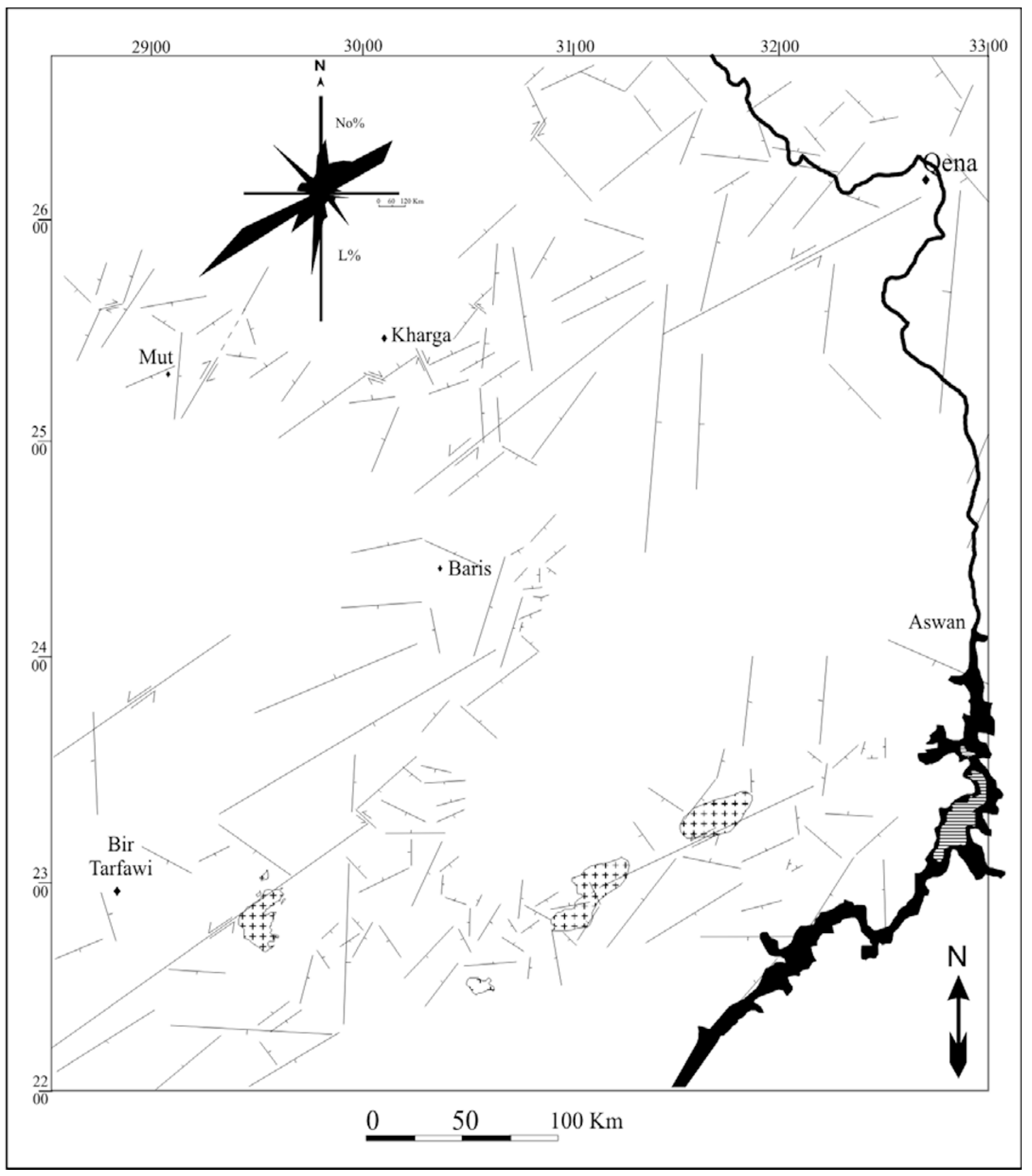

Fig. 7. Structure lineaments on the Bouguer anomaly map and its rose diagram shows that the main trends are E-W, N-S, N55 ${ }^{\circ}, \mathrm{N} 35^{\circ} \mathrm{E}$ and $\mathrm{N} 55^{\circ} \mathrm{W}$.

placement along the strike. This was interpreted as a result of horizontal movement (shearing) along these faults (Riad, 1977) of already folded or faulted blocks.

A total of 192 faults were identified all over the area. Linear Bouguer anomalies are commonly considered to be associated with vertical faults. The maximum length of faults detected in the study area is about $600 \mathrm{~km}$, which probably cuts the lower parts of the crust. Trend analysis was carried out for each faults category and the result is presented in the form of rose diagrams. Studding of the rose diagrams, representing the distribution of the length and number parameters of the faults against azimuth shows the presence of the following five fault trends arranged in a decreasing order: $\mathrm{N} 35^{\circ} \mathrm{E}, \mathrm{E}-\mathrm{W}, \mathrm{N}-\mathrm{S}, \mathrm{N} 55^{\circ} \mathrm{W}$ and $\mathrm{N} 55^{\circ} \mathrm{E}$. Four trends out of the recorded five $\left(\mathrm{N} 35^{\circ} \mathrm{E}, \mathrm{E}-\mathrm{W}, \mathrm{N}-\mathrm{S}\right.$ and $\left.\mathrm{N} 55^{\circ} \mathrm{E}\right)$ were found to represent ancient "deep-seated" as well as recent "near-surface" structures as they are detectable on both the Bouguer anomaly map as well as the stripped gravitycomponent maps. This means that they are penetrative and their print on the surface is clear and distinct. The remaining one registered trend $\mathrm{N} 55^{\circ} \mathrm{W}$ was found to represent only as recent "near-surface" structure. Riad (1977) interpreted the Bouguer anomaly map of the northern part of Egypt and shown the presence of almost parallel shear zones striking in a NW-SE direction, which are probably related to the interaction of the European and African plates.

Accordingly, we assume that this trend, which has been detected on the Bouguer anomaly map as well as gravity map of sedimentary rocks and disappeared in the gravity map on the top of the basement rock, result from shear fault 


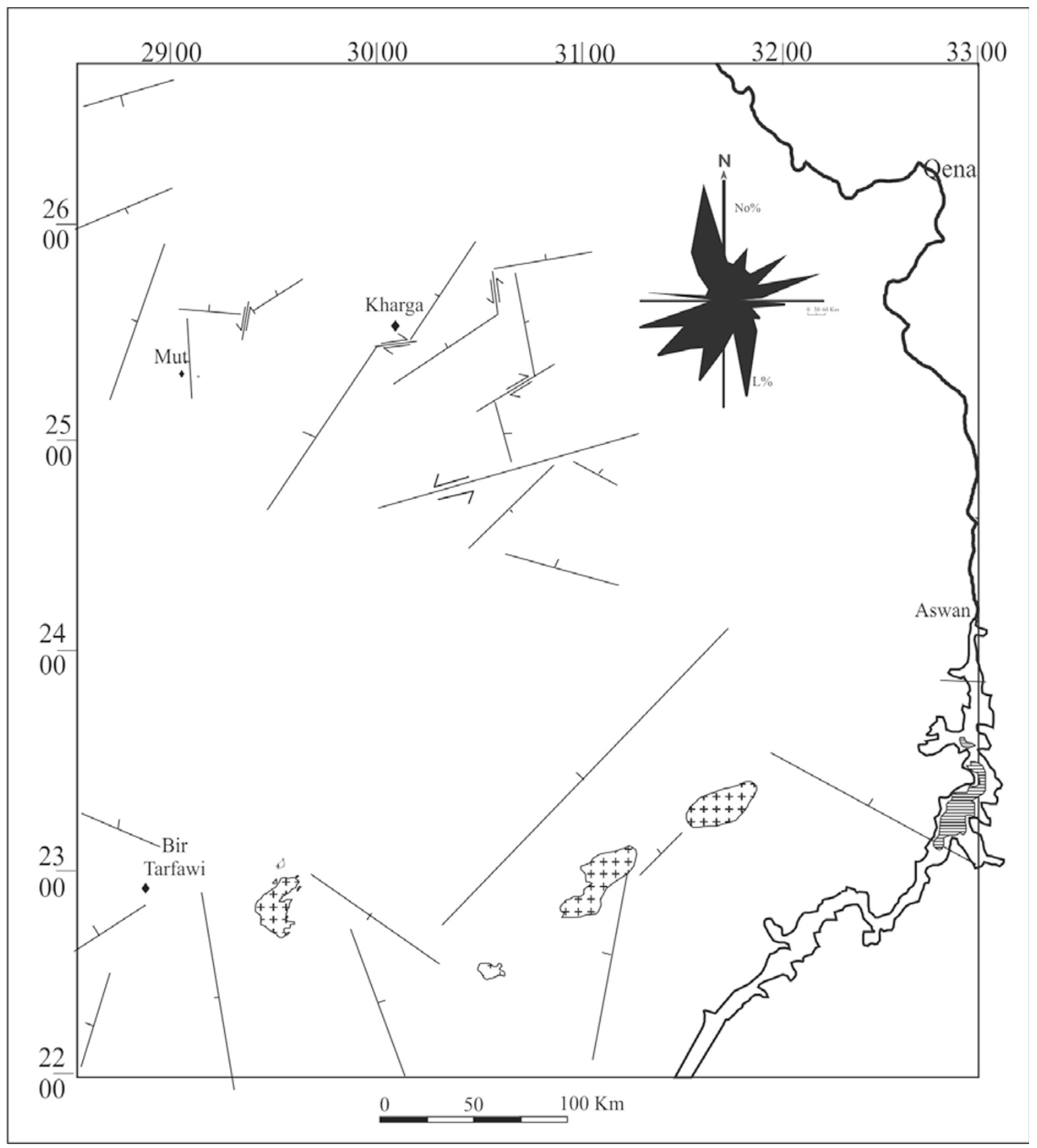

Fig. 8. Structure lineaments on the gravity anomaly map on the top of the basement rock and its rose diagram shows that the main trends are E-W, N-S, $\mathrm{N} 55^{\circ} \mathrm{E}$ and $\mathrm{N} 35^{\circ} \mathrm{E}$.

on sedimentary rocks and have no effect on the basement rocks.

\section{Isopach Map}

Generally, density of the underline rock formations increases with depth due to compaction. Based on this phenomenon many authors suggested mathematical expressions explaining the relation between density and depth. Artificial neural network (ANN) is a new data processing mechanism which transforms input data into desired output data using an internal architecture (Arbogast et al., 1998).

An Artificial Neural Network (ANN) is an information processing paradigm that is inspired by the way biological nervous systems, such as the brain, process information.
The novel structure of the information processing system represents the key element of this paradigm. It is composed of a large number of highly interconnected processing elements (neurones) working in unison to solve specific problems. ANNs, like people, learn patterns by experience.

Commonly neural networks are adjusted, or trained, so that a particular input leads to a specific target output. Such a situation is shown in Fig. 9. There, the network is adjusted, based on a comparison of the output and the target, until the network output matches the target. Typically many such input/target pairs are used, in this supervised learning, to train a network (Haykin, 2008).

The commonest type of artificial neural network consists of three groups, or layers, of units: a layer of "input" units is 


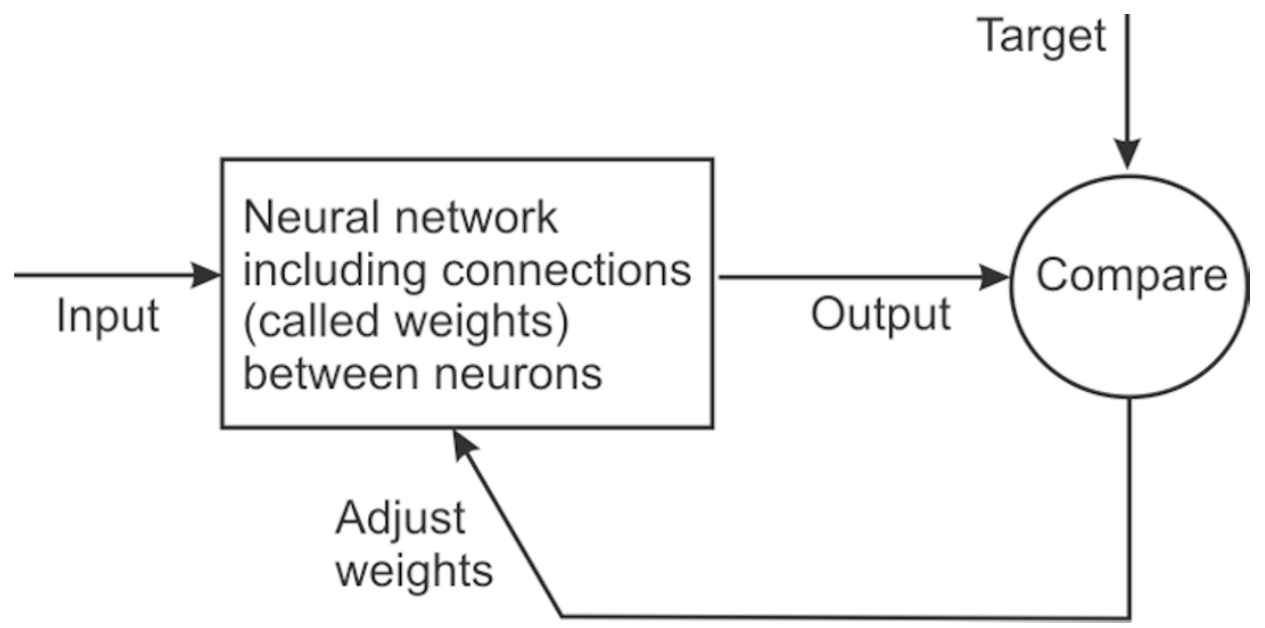

Fig. 9. Diagram shows the adjustment and training of the neural network based on a comparison of the output and the target, until the network output matches the target.

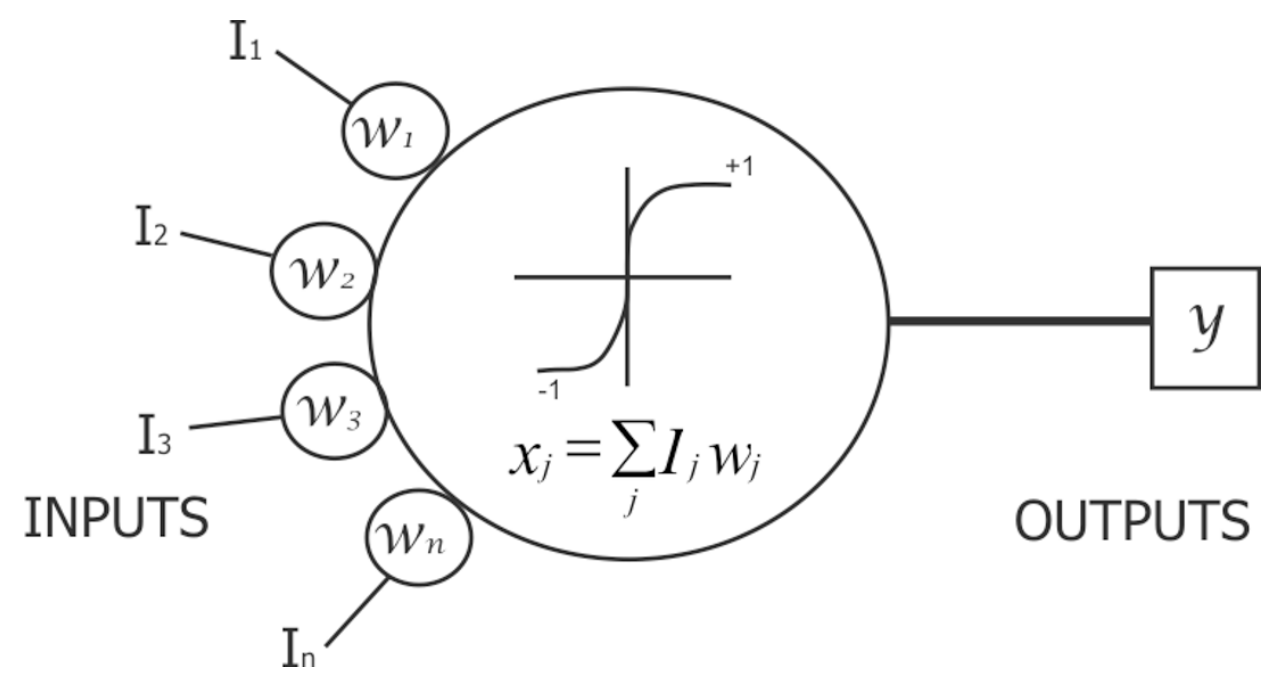

Fig. 10. A flow diagram of the active node used in the hidden and output layers of the neural network. Each input is multiplied by a weight, and then summed. This produces a single value that is passed through an "S" shaped nonlinear function called a sigmoid.

connected to a layer of "hidden" units, which is connected to a layer of "output" units (Fig. 10). The values in the output layers determined by following two step procedures, first it computes the total weighted input using the formula:

$$
x_{j}=\sum_{j} I_{j} w_{j}
$$

Next, the output values were calculated using some function of the total weighted input; typically we use the sigmoid function:

$$
y_{j}=\frac{2}{1+e^{-2 x}}-1
$$

Once the value of the output layer has been determined, the network computes the error $E$, which is defined by the expression:

$$
E=\frac{1}{2} \sum_{j}\left(y_{j}-d_{j}\right)^{2}
$$

Where $y_{j}$ is the output values and $d_{j}$ is the desired output values.
The next operation is to use back-propagation algorithm for training the ANN. Back propagation is a gradient descent system that tries to minimize the mean square error (MSE), which consists of four steps:

1. Compute how fast the error changes as the output changed

2. Compute how fast the error changes as the total input received by an output unit is changed

3. Compute how fast the error changes as a weight on the connection is changed

4. how fast the error changes as the input changed

This procedure was repeated to get minimum mean square error. In the present study, the architecture of ANN is illustrated schematically in Fig. 11 which depending on the input layer consists of the input parameters (gravity values), and the output layer which includes the desired parameters (thickness of sedimentary rock). The number of the neurons in the hidden layer (layers placed between input and output layers) was found to be seven neurons for sedimentary cover model and six neurons for sandstone layers. 

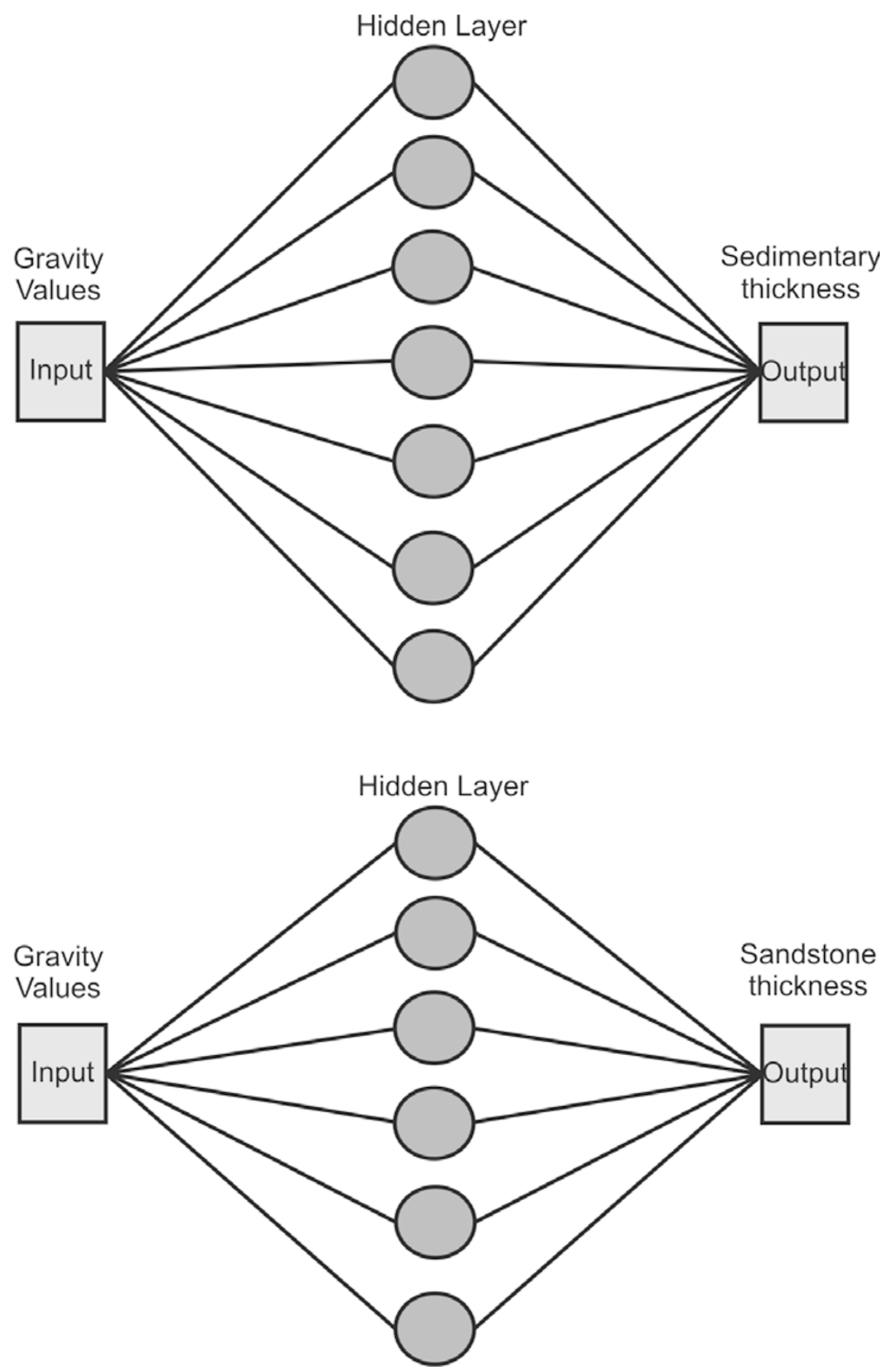

Fig. 11. Architecture of the used ANN for both the sedimentary cover and sandstone facies. The input layer consists of the input parameters (gravity values), and the output layer includes the desired parameters (thickness of sedimentary rock). The number of the neurons in the hidden layer was found to be seven neurons for sedimentary cover model and six neurons for sandstone layers.

Table 2. ANN design and training parameters for both whole sedimentary cover and sandstone layers.

\begin{tabular}{lcccccrcc}
\hline Model & $\begin{array}{c}\text { Input } \\
\text { layer }\end{array}$ & $\begin{array}{c}\text { Hidden } \\
\text { layer }\end{array}$ & $\begin{array}{c}\text { Output } \\
\text { layer }\end{array}$ & $\begin{array}{c}\text { Learning } \\
\text { rate }\end{array}$ & $\begin{array}{c}\text { Number of examples } \\
\text { used in training }\end{array}$ & $\begin{array}{c}\text { Number of } \\
\text { Epochs }\end{array}$ & $\begin{array}{c}\text { MSE } \\
\text { Correlation } \\
\text { coefficient }\end{array}$ \\
\hline Sedimentary rocks & 1 & 7 & 1 & 0.3 & 104 & 10,000 & 0.052 & 0.7803 \\
Sandstone layers & 1 & 6 & 1 & 0.1 & 104 & 5,000 & 0.067 & 0.7696 \\
\hline
\end{tabular}

In our ANN a different number of nodes in the hidden layer, training cycles and learning rates were selected. These parameters were changed and modified several times until satisfactory network design was reached. Table 2 shows the final best neural network architectures and training parameters.

Figures 12 and 13 show the error values for each training cycle against the number of epochs for the training sessions 


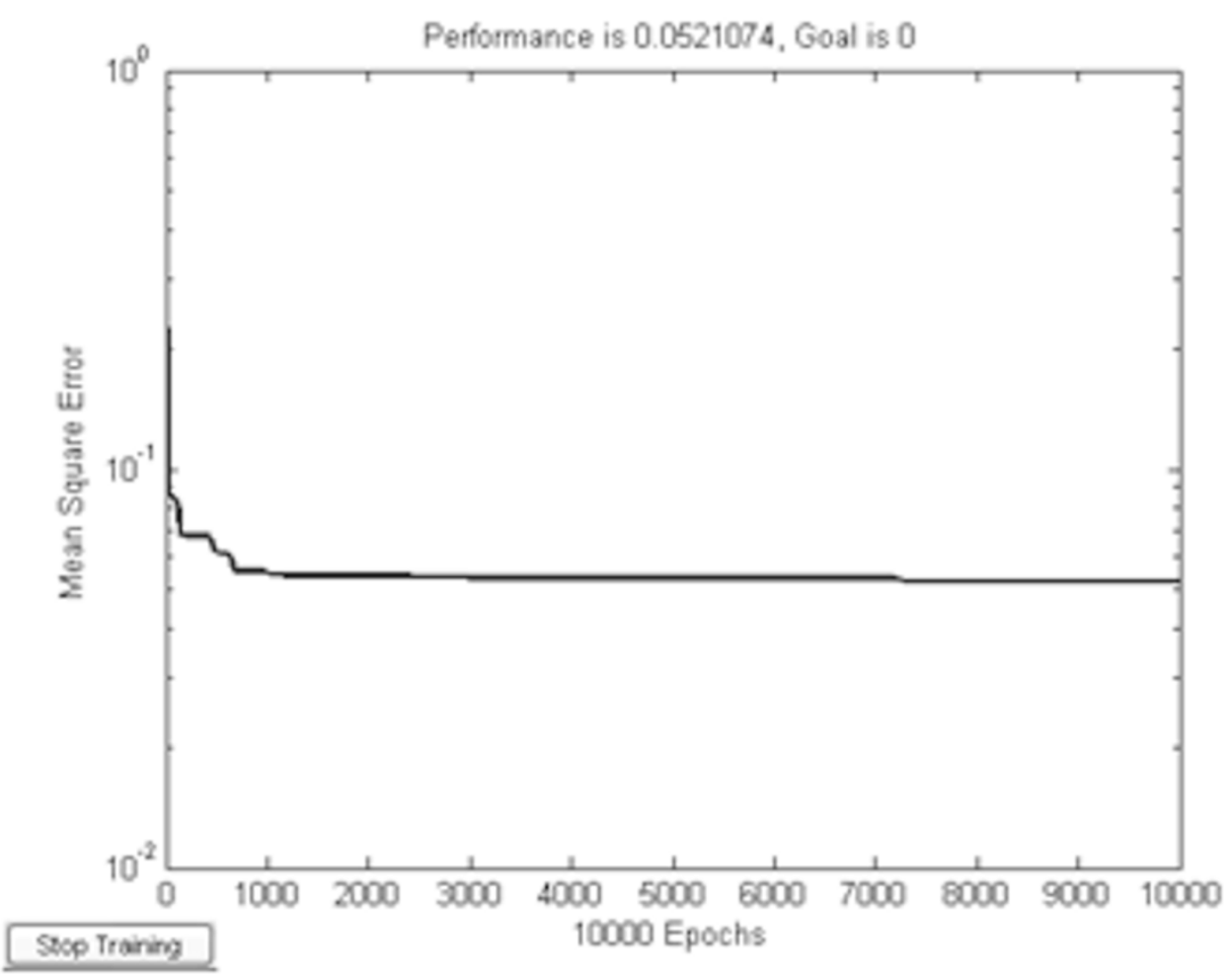

Fig. 12. Mean square error vs. epochs for all training stages for total sedimentary rock model. The used number of Epochs is 10,000 Epochs.

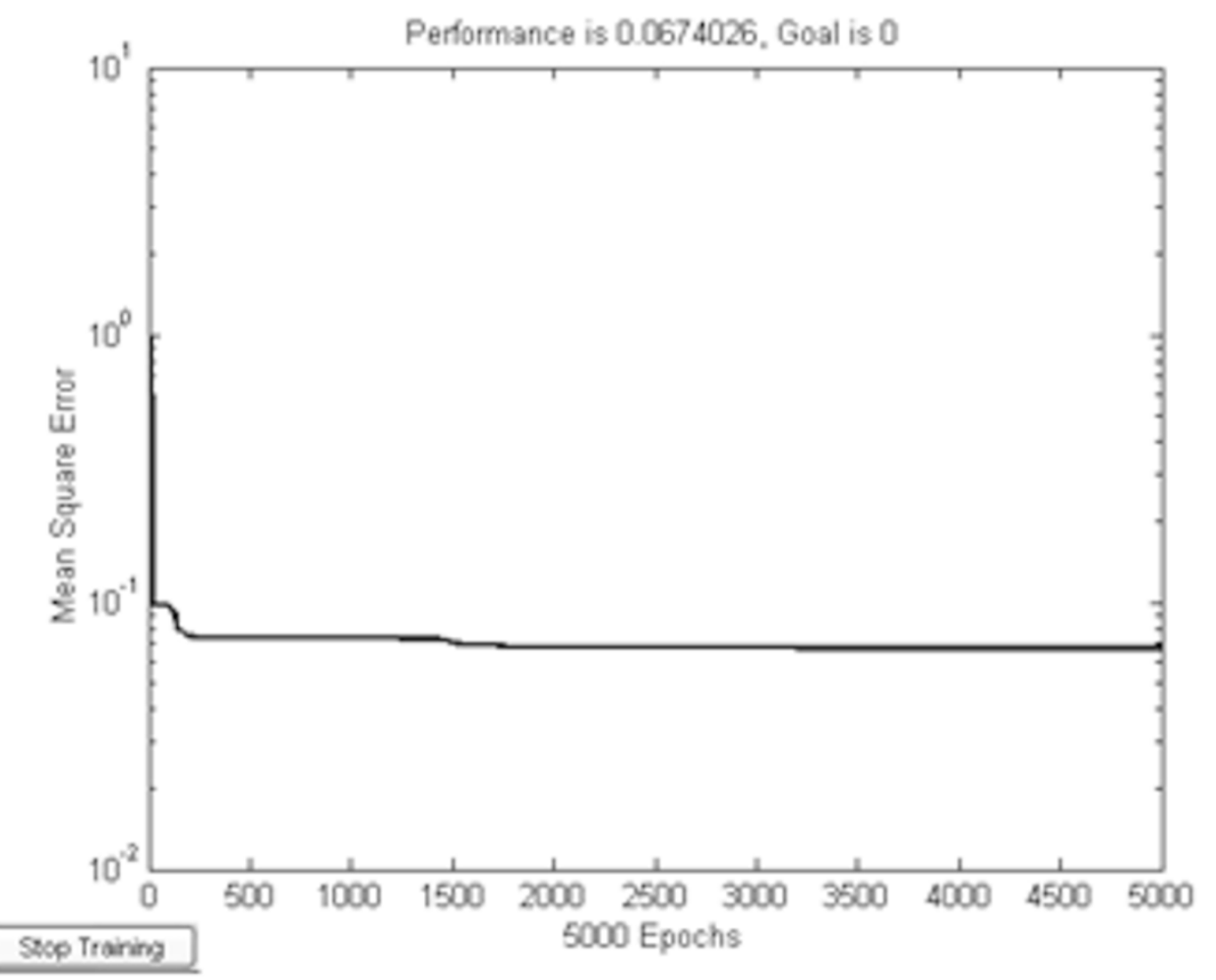

Fig. 13. Mean square error vs. epochs for all training stages for sandstone model. The used number of Epochs is 5,000 Epochs. 


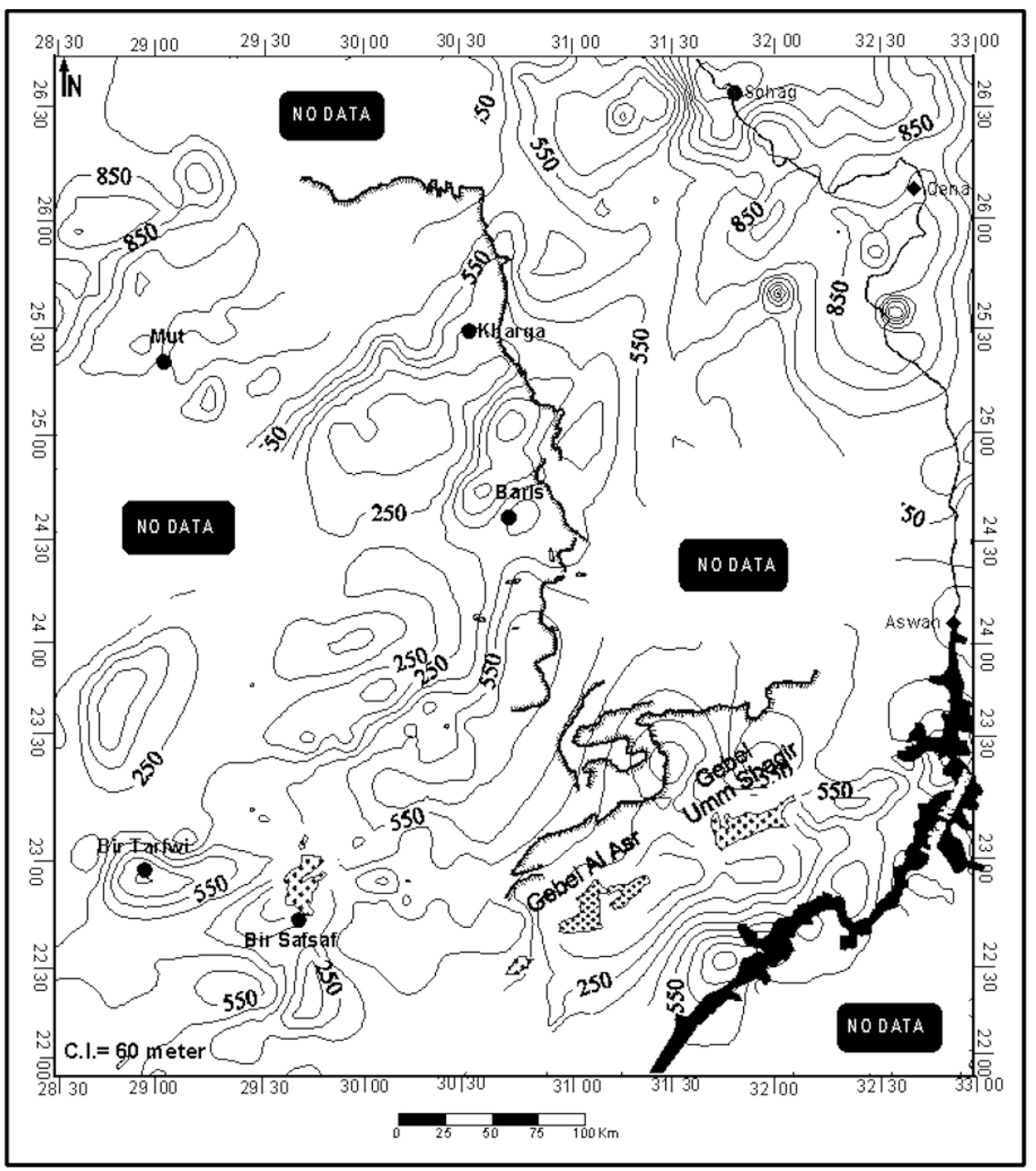

Fig. 14. Isopach map of the whole sedimentary cover with contour interval of $100 \mathrm{~m}$ shows that the thickness of the sedimentary cover increases towards the northeastern and northwestern part of the area.

of sedimentary cover and sandstone layers. We can recognize from these plots that at the beginning stage of the training the error of the model decreased rapidly while at the end of the training decreased slowly.

The comparison between the results from the ANN model and the observed depth from wells shows that the ANN model is the most powerful and most accurate for distinguishing the relationship between the sedimentary cover and the related gravity values (Table 3 ). So it is better to use the ANN model for drawing isopach map of both whole sedimentary layers and sandstone layers in the study area.

Visual inspection of the isopach maps of sedimentary cover and sandstone (Figs. 14, 15 respectively) reveals that the depth to the top of the basement rocks in the study area, ranges between 0 at the southern part and $1500 \mathrm{~m}$ below sea level (b.s.l) at the northeastern and northwestern parts of the area and the basement surface is characterized by the presence of many highs and lows. Two large highs can be recognized at the southern part of the study area at BirSafsaf and Gabel Umm Shaghir \& Gabel El Asr, where the basement crops out in these areas. To the north of this region the thickness of sedimentary rocks increases and reaches to more than $1000 \mathrm{~m}$ at Dakhla Basin. Isopach map of sandstone is very useful for ground water exploration because water is found in sedimentary series, which contain porous and permeable rock, so-called reservoir rock, and sandstone shows best reservoir rock. The chances of finding commercial quantities of ground water are greater at the 


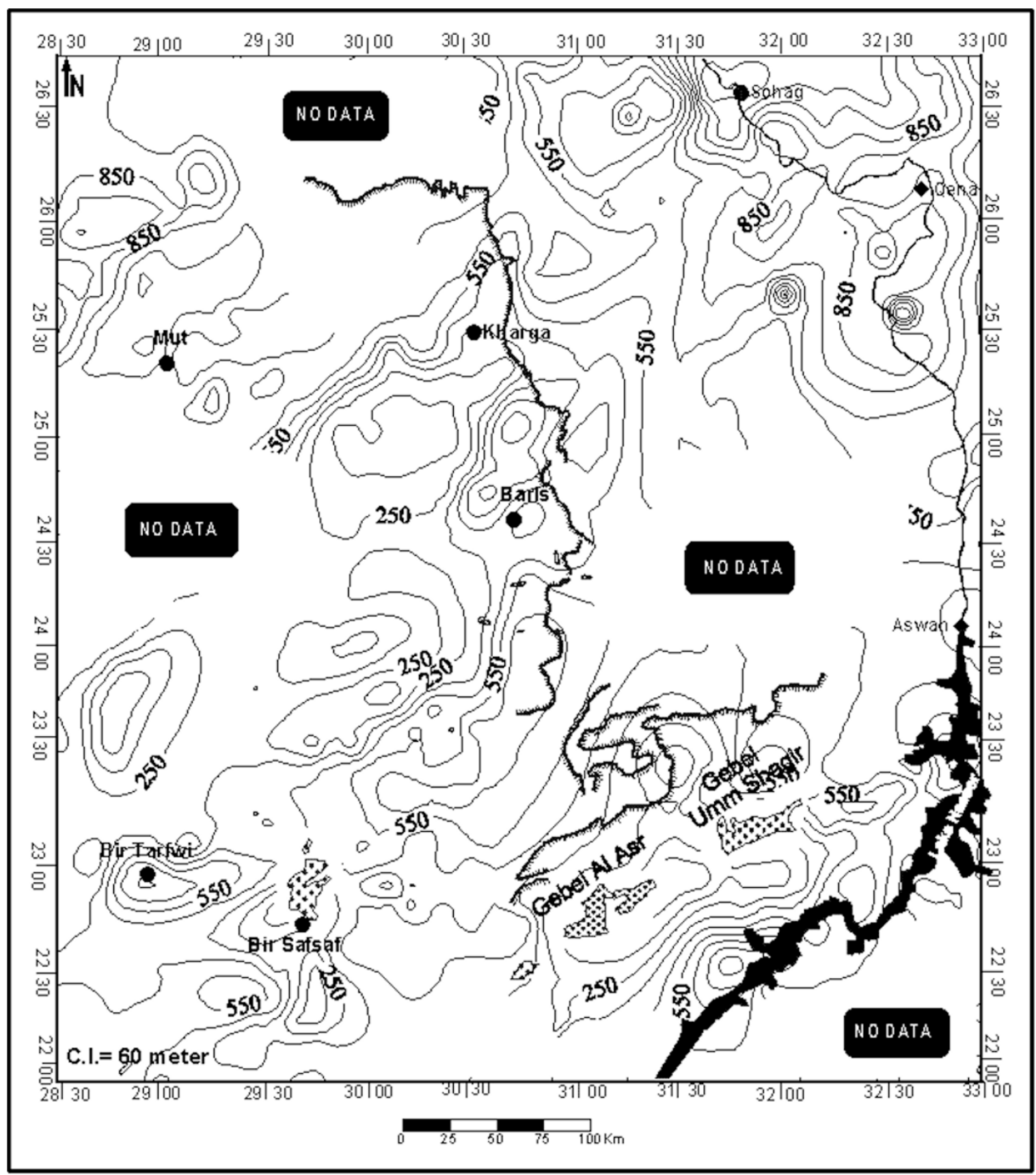

Fig. 15. Isopach map of the sandstone layers with contour interval of $100 \mathrm{~m}$. The chance of finding commercial quantities of ground water increase at the area containing a huge amount of sandstone rocks.

area containing a huge amount of sandstone rocks. From isopach map of sandstone, we can recognize that the area of Dakhla Basin and Nile valley Basin and some localities at southern part of the area in Tushka and West of El-Oweinat regions are considered as best localities for ground water exploration.

\section{Subsurface Cross Sections}

Cross-sections constitute an important geological tool. They are constructed in order to show both the vertical and the horizontal relationships among various rock bodies. The sections also constructed in order to show structural relationships using the sea level as the plane of reference. Two subsurface geological cross-sections $\mathrm{AA}^{\prime}, \mathrm{BB}^{\prime}$ were constructed (Figs. 16, 17 respectively) and compared with two gravity profiles were constructed from Bouguer anomaly map and gravity map on the top of the basement rock in order to explain the relation between gravity values and thickness of sedimentary rocks. These profiles show that the maximum values coincide with the basement outcrops on the sections, while in contrast the minimum values point out to thick sedimentary cover. Along these cross sections estimated depths from the ANN model were plotted in between the locations of the wells and show a good correlation between the observed and determined depths. 


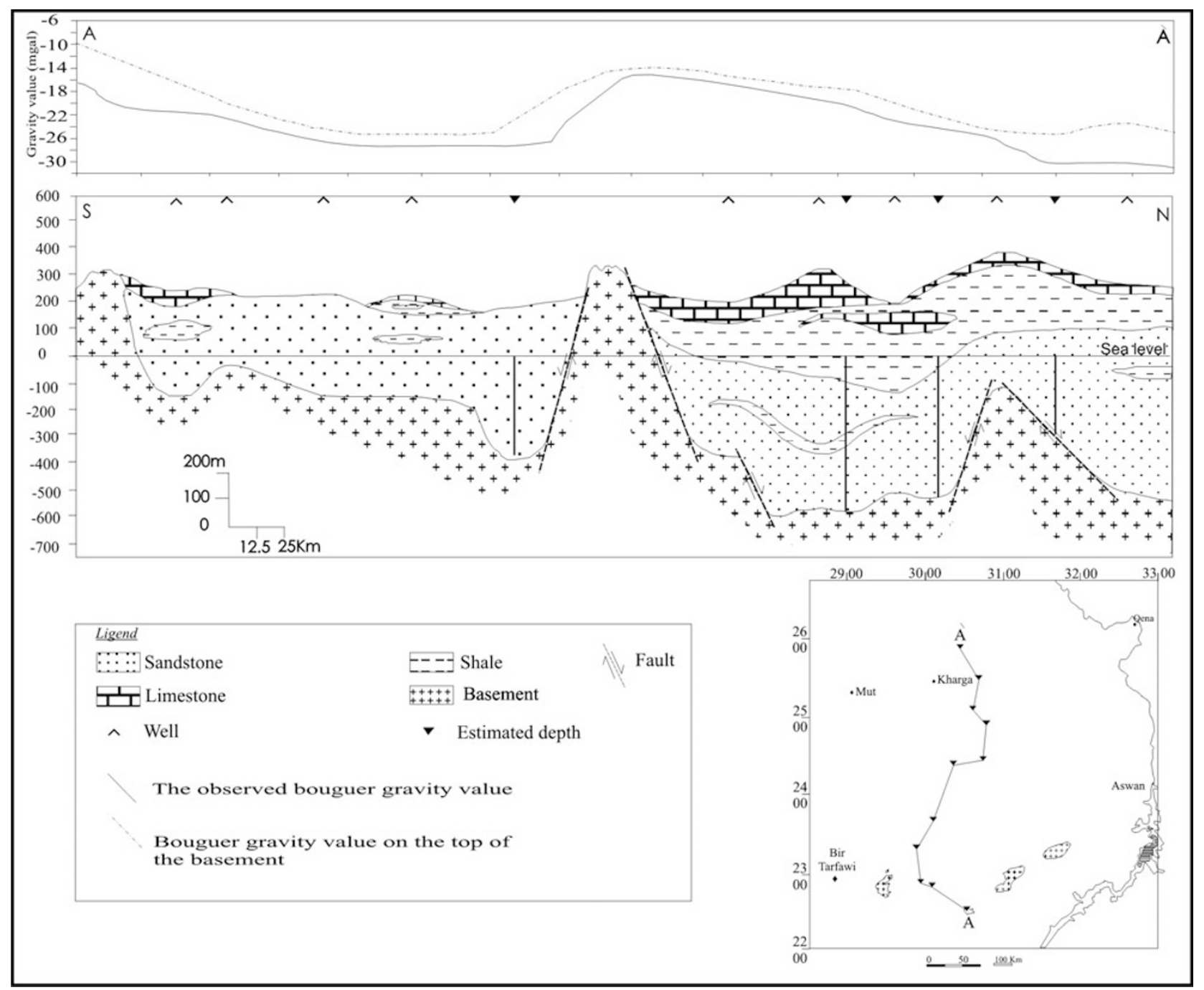

Fig. 16. North-south $\mathrm{AA}^{\prime}$ cross section and its corresponding gravity profiles show a good correlation between high gravity values and uplifts on basement rocks.

Table 3. Comparison between the observed and estimated depth.

\begin{tabular}{ccccccc}
\hline Well number as in Fig. 4. & Well name & Gravity value & Thickness & Elevation & Observed depth & $\begin{array}{c}\text { Estimated depth by } \\
\text { ANN model }\end{array}$ \\
\hline 24 & Bulaq 2 & -26 & 733 & 180 & 553 & 550.53 \\
30 & Bulaq 8 & -9 & 760 & 270 & 490 & 500 \\
45 & Baris 3 & -29 & 383 & 90 & 293 & 310 \\
53 & Balat 15 & -30 & 1011 & 240 & 771 & 742 \\
95 & Pro1 Site 1 & -22 & 200 & 28 & 172 & 240 \\
83 & W3-deep & -18 & 400 & 89.53 & 310.47 & 360 \\
\hline
\end{tabular}

\section{Conclusion}

The study area occupies the Southern part of the Western Desert of Egypt. The Bouguer gravity map of the study area is interpreted in order to define the vertical and lateral variations in the mass distribution. In the present study, stripping techniques was applied in the Bouguer gravity map for separating the anomalies of sedimentary and basement rocks. The Bouguer gravity map and stripped gravity maps show the main irregularities in the gravitational field caused by uplifting or subsiding of the surface of basement rocks due to tectonic movements. Four trends out of the recorded five (E-W, N-S, N55 ${ }^{\circ} \mathrm{E}$, and $\mathrm{N} 35^{\circ} \mathrm{E}$ ) were found to represent deep-seated as well as near-surface structures as affect the basement rocks and propagate upward through the sedimentary cover as deduced from the analysis of the gravity lineaments derived from the gravity maps. The remaining one registered trend $\mathrm{N} 55^{\circ} \mathrm{W}$ was found to represent only near-surfac structure because of its absence of the regional and its existence only on gravity maps of sedimentary rocks. Isopach maps were made based on a reverse relationship 


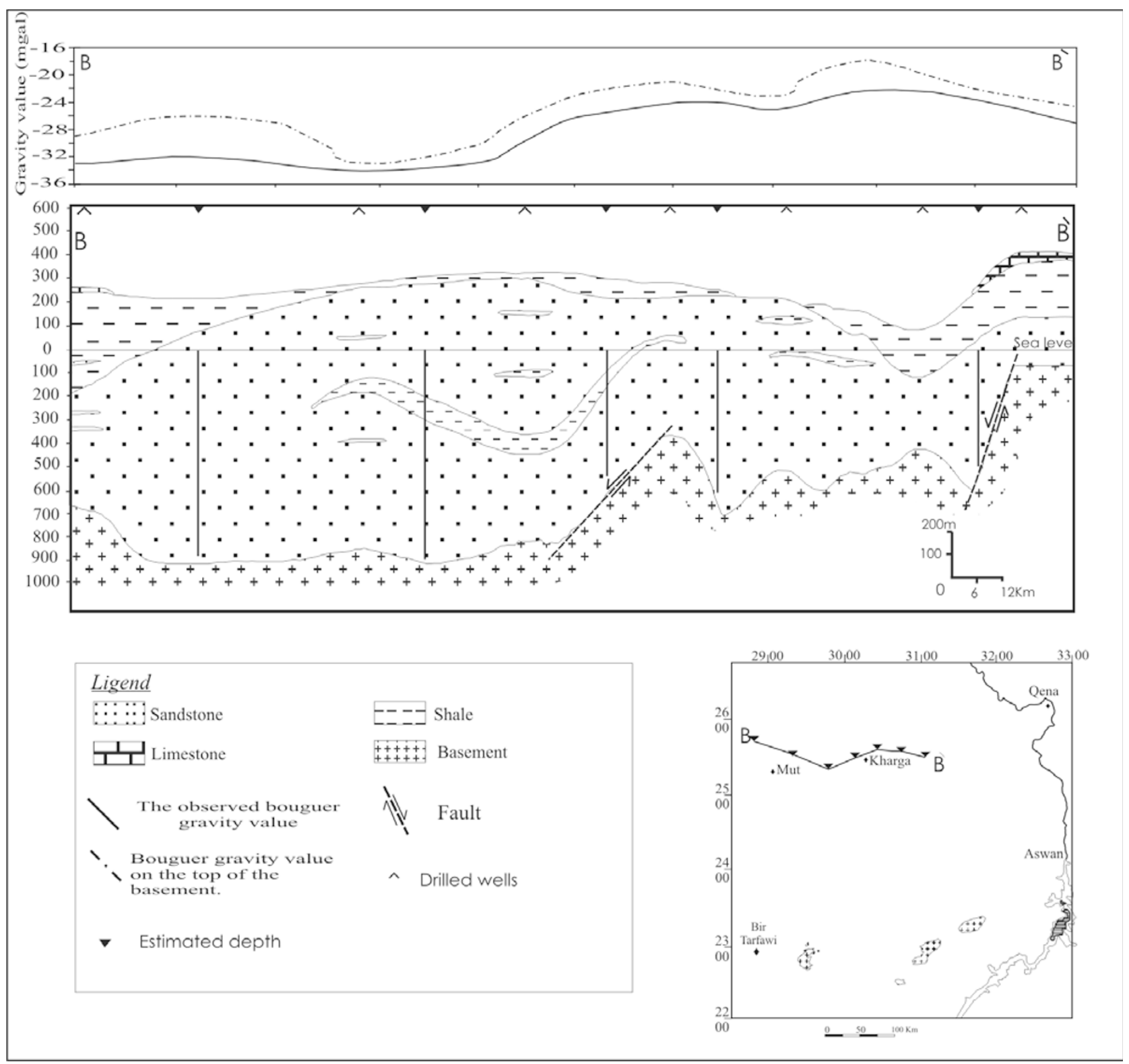

Fig. 17. East-west $\mathrm{BB}^{\prime}$ cross section and its corresponding gravity profiles. The lowest gravity values correlated with high thickness of sedimentary cover.

between depth of the sedimentary rock and its equivalent gravity value by constructing of neural network model in that area. Isopach maps show that the depth to the top of the basement rock ranges between 0 and $1500 \mathrm{~m}$ (b. s. 1.) and that the maximum thickness of sedimentary cover observed in Dakhla Basin and north of Nile valley Basin at the west of Qena city. The chance of finding commercial quantities of ground water is greater at the areas containing a huge amount of sandstone rocks. Consequently the isopach map of sandstone, representing the best reservoir rocks, is very useful for ground water exploration. Five cross sections have been constructed to show the structural relationship and to emphasize the quantitative interpretation process. These cross sections were correlated with their corresponding gravity profiles to show the relationship between the gravity values and thickness of sedimentary cover and consequently the irregularities on the basement surface.
Acknowledgments. I would like to express my great indebtedness and my deepest thanks to Geology Department, Faculty of Science, Assiut University for their continuous help. Also I would like to express my gratitude to the Geothermic Laboratory staff, Earth Resource Engineering, Kyushu University for discussing the result. And I greatly indebt to Mr. Saleh Haridy, Department of Intelligent Systems, Kyushu University, Laboratory for Image and Media Understanding for his help in ANN construction.

\section{References}

Abu El-Ata, A. S. and S. H. Abd El-Nabi, Mapping the structural elements dissecting the Cretaceous rock units of the Qattara depressions area, western Desert, Egypt; using three-dimensional gravity modeling, Geological Survey of Egypt, Proc. Of 4th Ann. M., pp. 103-123, 1985.

Arbogast, J. S., M. H. Franklin, M. L. Butler, and K. A. Thompson, Enhancement of limited log suites using neural networks, SPE, Annual Technical Conference and Exhibition, San Antonio, Texas, pp. 10, 1998. Barakat, M. G. and G. S. Milad, Subsurface geology of the Dakhla oasis, Egypt, J. Geol., 10(2), 145-154, 1966.

Bernau, R., D. P. F. Darbyshire, G. Franz, U. Harms, A. Huth, N. Mansour, Pasteel, and H. Schandelmeier, Petrology, geochemistry and structural 
development of the Bir Safsaf-Aswan uplift, Southern Egypt. J. Afr. Earth Sci., 6(1), 79-90, 1987.

Conoco Coral, Geological Map of Egypt, Scale 1:500,000, Cairo, Egypt, Egyptian General Petroleum Corporation (EGPC), 1987.

Egyptian General Petroleum Corporation (E. G. P. C), Bouguer anomaly map of South Western desert of Egypt, scale 1:500,000, 1980.

El-Etr, H. A., M. A. Yehia, and H. Dowidar, Fault pattern in the South Western Desert of Egypt; Mid., F., Res. Cent Ain Shams Univ. Sci. Res. Series Vol. 2, pp. 123-151, 1982.

Haykin, S., Neural Network and Learning Machines, Prentice Hall PTR Upper Saddle River, NJ, USA, 860 p, 2008.

Heinl, M. and U. Thorweihe, Groundwater resources and management in SW Egypt, in Geopotential and Ecology, Meissner, M. and P. Wycisk, 99-121, Cremlingen-Destedt, Germany, 1993.

Hendriks, F., P. Lugar, H. Kallenbach, and J. H. Schroeder, Stratigraphical and sedimentological framework of the Kharga-Sinn-EL-Kaddab stretch, Western and Southern part of the upper Nile basin, Western Desert, Egypt, Berliner geowiss., Abh., (A), 50, 117-151, 1984.

Nettleton, L. L., Gravity and Magnetics in oil prospecting, 464 p, Mc-
Graw Hill Book Co., New Yourk, 1976.

Parasniss, D. S., Principles of applied geophysics, 5th ed., p. 429 Chapman \& Hall, 2-6 Boundary Row, London Se 18 Hn, UK, 1997.

Riad, S., Shear zones in north Egypt interpreted from gravity data, Geophys., 24(6), 1207-1214, 1977.

Said, R., The geology of Egypt, 337 p, Amstrdam-New York, Elsiver Publishing Co., 1962.

Senosy, M., Application of density contrast stripping in studying subsurface geologic structures: a case study El-Kharga Oasis, western Desert, Egypt, Egyptian J. Geol., 47, 387-404, 2003.

Telford, W. M., L. P. Gelbart, R. E. Sheriff, and D. A. Keys, Applied geophysics, 770 p, Cambridge Univ., press, Cambridge, 1990.

Wycisk, P., Contribution to the subsurface geology of the Misaha trough and the Southern Dakhla Basin, Berliner geowiss., Abh., (A), 75.1, 137$150,1987$.

M. Abdel Zaher (e-mail: mohamed-zaher@mine.kyushu-u.ac.jp), M. M. Senosy, M. M. Youssef, and S. Ehara 